\title{
Analysis of Prefabricated Systems in the Construction of Family Houses
}

\author{
Alena Tažiková, Juraj Talian, Jozef Galla \\ Technical University of Košice, Faculty of Civil Engineering, Vysokoškolská 4, 04200 Košice, Slovakia
}

\begin{abstract}
At the moment the human is trying to make the construction as efficient as possible, accelerate and facilitate the introduction of different types of innovations. Therefore, to the fore a new concept of prefabrication, which we call modern methods of construction MMC is coming. In this article, 3 prefabricated construction systems were chosen for the analysis of the construction of the family house. It is a system of Europanel SIP technology, CLT panels and ceramic panels. These are systems of euro panels' technology SIP, CLT panels and ceramic panels. The choice of construction systems has taken into account that all three systems fall under the MMC philosophy. Subsequently, selected parameters of individual structural systems were analysed, such as wall thickness, ceiling thickness, bulk density, compressive strength of walls, heat transfer coefficient, reaction to fire, fire resistance, usable area and price on a particular family house project.
\end{abstract}

Keywords - prefabrication, MMC, SIP technology, CLT panels, ceramic panels, family houses.

\section{Introduction}

Nowadays, as well as in other sectors of the economy, the emphasis in the construction industry is on its industrialization - introducing intelligence in the spirit of Industry 4 theory.

DOI: $10.18421 /$ TEM93-17

https://doi.org/10.18421/TEM93-17

Corresponding author: Alena Tažiková, Technical University of Košice, Faculty of Civil Engineering, Vysokoškolská 4, 04200 Košice, Slovakia Email: alena.tazikova@tuke.sk

Received: 26 June 2020.

Revised: 24 July 2020.

Accepted: 30 July 2020.

Published: 28 August 2020.

(cc)Br-NC-ND@C 2020 Alena Tažiková, Juraj Talian \& Jozef Galla; published by UIKTEN. This work is licensed under the Creative Commons Attribution-NonCommercialNoDerivs 4.0 License.

The article is published with Open Access at www.temjournal.com
Generally speaking, today's builders require the individually produced products and services construction work, building objects and entire buildings ("Made-for-Me"). Construction industry is trying to incorporate smart objects, products and machines in its production. These smart objects allow manufacturers to produce a piece production of various prefabricated panels and at the same time to produce the original part of the building structures, without increasing costs, with different variability. This philosophy pushes to the forefront a new understanding of prefabrication, compared to the understanding of prefabrication, which was established in the centrally controlled economy before 1989. Understood in this way, prefabrication belongs under the philosophy of Modern methods of construction - MMC. Modern methods of construction (MMC) are a long-term concept, which includes a number of manufacturing processes and techniques in the construction that provide alternatives to traditional methods of construction. The study that involves 18 organizations has been recently implemented in the United Kingdom, which had to express opinions regarding the experience and the use of technology MMC, shown in Figure 1 and Figure 2. In the framework of the survey in 2018 [1], $61 \%$ of builders said they were using or were prepared to use an offsite volumetric modules, $61 \%$ of builders said they were using or were prepared to use an offsite panelized systems, $28 \%$ were using an offsite hybrid systems and 39\% used Onsite MMC methods.

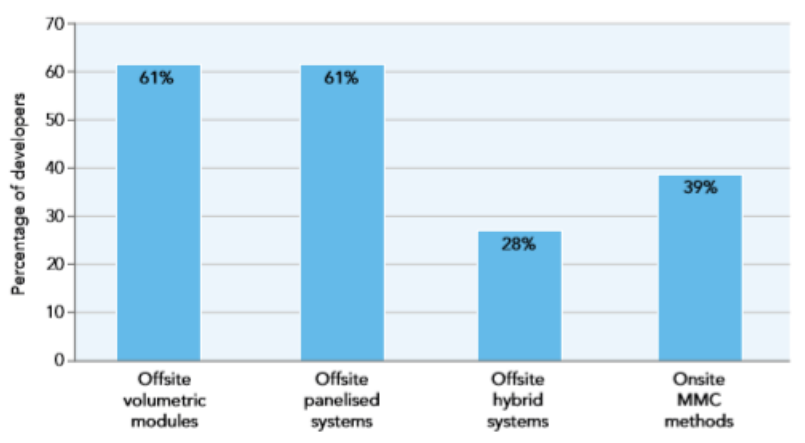

Figure 1. Proportion of developers using or planning to use different types of MMC [1] 


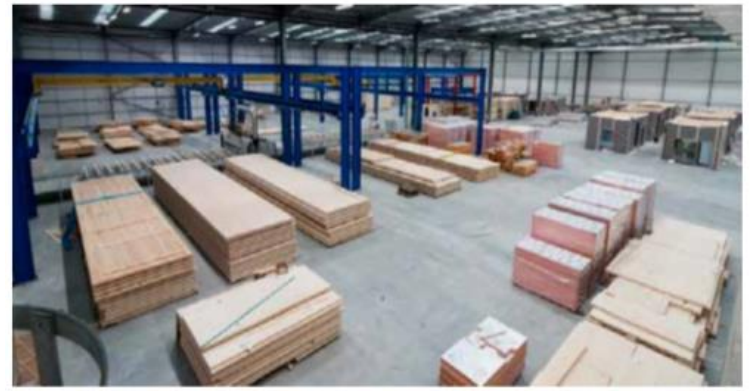

Figure 2. Modern methods of constructioon:views from the industry. NHBC Foundation. NF70, 2016 [1]

Since it is not possible to forget that the introduction of new innovation both in the world and also in Slovakia, may carry a whole series of problems, such as high input costs machinery lines and the existing demand for traditional building systems. Within the use of MMC, various studies describe the advantages and disadvantages of these technologies. These advantages and disadvantages vary from country to country [2], [3]. The use of MMC methods is intended to ensure the speed and efficiency of construction. The question remains for which target groups the given type of construction is intended [4]. Modern methods of wood-based construction ensure that the conditions of sustainability are observed within the life cycle of the construction [5], [6]. Sustainability in construction contributes to the decision-making process for future construction [7], [8]. Scientists also deal with the evaluation of the life cycle in wooden buildings [9], [10], [11]. There are various studies of wooden buildings around the world that confirm their sustainability [12], [13]. The wood-based material is renewable and its use reduces the carbon footprint of the built-in material [14]. The construction of wooden houses meets the conditions of off-site construction and can be modeled in the factory [15]. Wood-based modular construction is strongly supported by legislation in the United Kingdom, Canada, the USA and the Scandinavian countries [16]. For wooden buildings, their energy consumption and economic efficiency are also monitored [17], [18]. The construction of wooden houses should contribute to the protection of the environment with regard to the entire life cycle of the construction [19], [20]. MMC offers safer and faster manufacturing, quality and environmentally friendly solution [21], [22]. The article deals with the cost analysis of the selected MMC in Slovakia, in the segment of family house.

\section{Methodology}

Time for the analysis regarding the construction of the family house, from prefabricated elements (Figure 3), selected 3 structural designs of prefabricated systems. These are systems of euro panels' technology such as SIP, CLT panels and ceramic panels. In the selection of construction systems, we took into account that all three systems fall under the MMC philosophy. The following parameters were mainly monitored:

- Technical and physical parameters of prefabricated systems

○ Thermal insulation properties

○ Fire safety

- Room area for each prefabricated system

$\circ$ Living area and area of family house accessories

- Price of construction material, labor and transport to the construction site of the implementation companies

Analyzed building is classified as new building of family house. The ground plan of the house is rectangular in shape (Figure 4, Figure 5). The builtup area of the building is $89,06 \mathrm{sqm}$. The slope of the roof is 35 degrees.

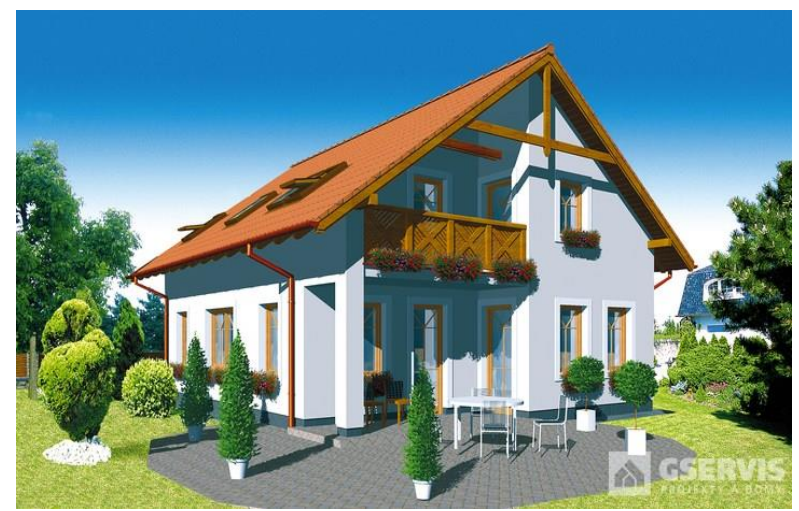

Figure 3. Architecture of family house, made of prefabricated elements [24]

Family house will be located in the village Plaveč in the district of Stará L'ubovña in Slovakia. The place will be demarcated as a piece of land which does not fall between the protected areas. The land is flat with access to a local communication from the western side. Engineering networks are made out on the plot. 

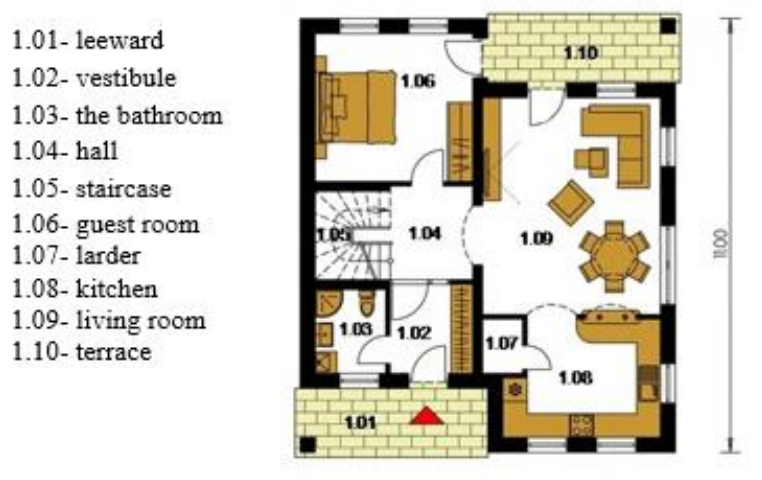

Figure 4. First floor rooms (1st floor) [24]
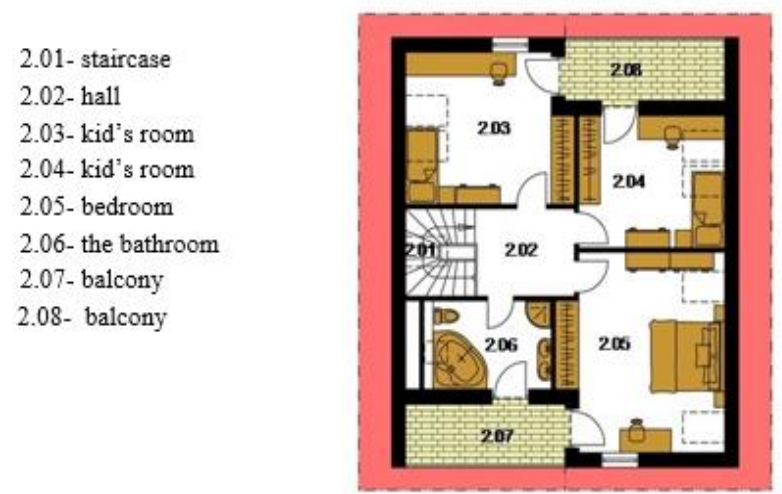

Figure 5. Second floor rooms (2st floor) [24]

Technology of ceramic composite panels implies (Figure 6): the prefabricated walls will be constructed continuous of the ceramic fiber composite (siopor, liapor) with thermal insulation added in production. The thickness of the perimeter wall panels is $150 \mathrm{~mm}+30 \mathrm{~mm}$ insulation, which is delivered at the factory. The thickness of the bearing walls is $120 \mathrm{~mm}$, and the thickness of the non-load bearing partitions is $100 \mathrm{~mm}$. By combining the four major components siopor, liapor, cement and special ingredients, a unique building material is created. From the unique materials such as ceramic composite, prefabricated ceramic parts are mounted so-called ceramic houses. These materials stand out due to interesting properties. They are firm, noncombustible, and lightweight, and they have good thermal insulation properties.
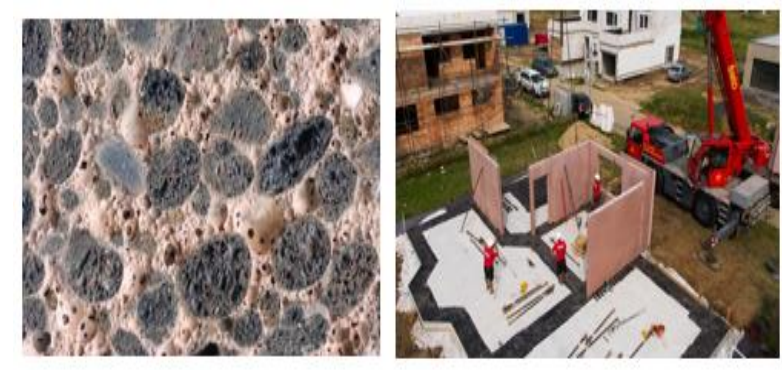

Figure 6. ceramic composite and ceramic composite panels [23]
By mixing concrete with these materials, the concrete will have different properties than common concrete. Mixed concrete takes properties of the added materials - siopor and liapor.

Technology of construction of CLT panels (Figure 7): the walls of the prefabricated panels CLT will be made by gluing at least three layers slats with the indication of $90 \mathrm{C} 3 \mathrm{~s}$ from spruce wood. The thickness of the wall panels (load-bearing external and internal) is $90 \mathrm{~mm}$. Thanks to the high degree of prefabrication of construction parts - the panels are from the production of indoor structure with millimeter precision, are energy efficient with a fast time of construction (up to $150 \mathrm{sqm}$ per day) even during the winter months. For the realization of the family house there is no need for special projects and use all the available projects on the market, which were originally intended for another structural system. Advantages of the system are as follows:

- No special projects required;

- All available projects on the market are applicable;

- One gets approx. $10 \%$ of the floorage more than in the classic materials;

- One can also build in winter;

- The implementation is also possible by us;
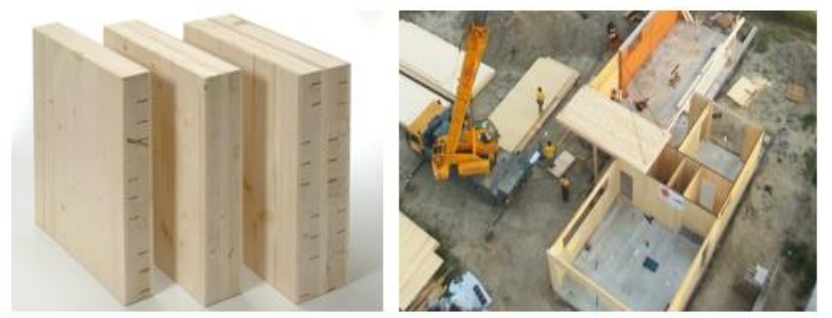

Figure 7. CLT panels and construction of the family house from the CLT panels [23]

Technology of construction from SIP panels (Figure 8): The construction of the house is made from prefabricated euro panels with technology of SIP (structural insulating panel).


Figure 8. SIP panels and construction of the family house from the SIP panels [23]

This technology consists of sandwiched panels made of wood-based material and filled with expanded polystyrene, which serves as both a 
thermal and sound insulator. It is a modern system of production for low-energy buildings. Prefabricated euro panel consists of two outer OSB boards whose thickness is $15 \mathrm{~mm}$ and the core of the extruded polystyrene EPS, the thickness of $140 \mathrm{~mm}$. The total thickness of the external cladding is $170 \mathrm{~mm}$. The inner bearing walls are $120 \mathrm{~mm}$ thick. SIP panels are versatile; they are used for making floors, ceilings, walls, partitions and roofs. They can be used for the construction of residential, commercial, educational, health care institutions and homes, guaranteeing environmental security and modern energy efficiency.

\section{Results and Discussion}

The results of the comparisons of all three panel systems are shown in Table 1. The thinnest thickness of the external walls is in the constructional solutions from the CLT panels, where the thickness is only $90 \mathrm{~mm}$, but assuming that all internally walls will be $90 \mathrm{~mm}$ thick for ensuring the static requirements. The thickness of the external walls of the ceramic panels is in turn the thickest with thickness of $180 \mathrm{~mm}$, and that of which $30 \mathrm{~mm}$ is the thermal insulation supplied in the factory. When looking at the volume weight, the lowest has euro panel technology SIP $125 \mathrm{~kg} / \mathrm{m} 3$, but it also has the lowest strength in the pressure $1 \mathrm{MPa}$. The ceramic panel variant provides us with the highest volume weight of $720 \mathrm{~kg} / \mathrm{m} 3$, but also the highest compressive strength of $6 \mathrm{MPa}$. CLT panels have the volume weight of $470 \mathrm{~kg} / \mathrm{m} 3$ and a compressive strength of 2,7 MPa. In the comparison of these two parameters is a variant of the CLT panels, the middle path.

Table 1. Properties of panel systems

\begin{tabular}{||c|c|c|c|c|c|c||}
\hline \multirow{2}{*}{$\begin{array}{c}\text { Wall } \\
\text { thickness }\end{array}$} & $\begin{array}{c}\text { External } \\
\text { walls }\end{array}$ & $\begin{array}{c}\text { Load- } \\
\text { bearing } \\
\text { walls }\end{array}$ & $\begin{array}{c}\text { Non- } \\
\text { bearing } \\
\text { walls }\end{array}$ & $\begin{array}{c}\text { External walls, } \\
\text { load-bearing } \\
\text { walls and non- } \\
\text { bearing walls }\end{array}$ & $\begin{array}{c}\text { External } \\
\text { walls }\end{array}$ & $\begin{array}{c}\text { Non- } \\
\text { bearing } \\
\text { walls }\end{array}$ \\
\cline { 2 - 6 } & $150+30 \mathrm{~mm}$ & $120 \mathrm{~mm}$ & $100 \mathrm{~mm}$ & $90 \mathrm{~mm}$ & $170 \mathrm{~mm}$ & $120 \mathrm{~mm}$ \\
\hline $\begin{array}{c}\text { Ceiling } \\
\text { thickness }\end{array}$ & $180 \mathrm{~mm}$ & $120 \mathrm{~mm}$ & $210 \mathrm{~mm}$ \\
\hline $\begin{array}{c}\text { Volume } \\
\text { weight }\end{array}$ & $720 \mathrm{~kg} / \mathrm{m}^{3}$ & $470 \mathrm{~kg} / \mathrm{m}^{3}$ & $125 \mathrm{~kg} / \mathrm{m}^{3}$ \\
\hline $\begin{array}{c}\text { Compressive } \\
\text { strength of } \\
\text { walls }\end{array}$ & $6 \mathrm{MPa}$ & $2,7 \mathrm{MPa}$ & $1 \mathrm{MPa}$ \\
\hline $\begin{array}{c}\text { Thermal } \\
\text { conductivity } \\
\text { coefficient }\end{array}$ & $0,05 \mathrm{w}(\mathrm{m} / \mathrm{k})$ & $0,11 \mathrm{w}(\mathrm{m} / \mathrm{k})$ & $0,11 \mathrm{w}(\mathrm{m} / \mathrm{k})$ \\
\hline $\begin{array}{c}\text { Thermal } \\
\text { resistance }(\mathrm{R})\end{array}$ & $3,6 \mathrm{~m}^{2} . \mathrm{K} / \mathrm{W}$ & $0,82 \mathrm{~m}{ }^{2} . \mathrm{K} / \mathrm{W}$ & $3,73 \mathrm{~m}{ }^{2} . \mathrm{K} / \mathrm{W}$ \\
\hline $\begin{array}{c}\text { Heat-transfer } \\
\text { coefficient } \\
\text { (U) }\end{array}$ & $0,26 \mathrm{~W} /\left(\mathrm{m}^{2} . \mathrm{K}\right)$ & $1,01 \mathrm{~W} /\left(\mathrm{m}^{2} . \mathrm{K}\right)$ & $0,25 \mathrm{~W} /\left(\mathrm{m}^{2} . \mathrm{K}\right)$ \\
$(\mathrm{HR}) .170 \mathrm{~mm})$
\end{tabular}

In selecting a suitable design solution, the thermal insulation properties play an important role in the decision-making process. The basic parameters for determining these properties are mainly the heat transfer coefficient (U) or the thermal resistance $(\mathrm{R})$. Since 2013, for buildings classified as low-energy for external walls, the construction-technical standard (STN 73 0540-2, 2012) prescribes a value of the heat transfer coefficient $\mathrm{U}=0.22 \mathrm{~W} /(\mathrm{m} 2 . \mathrm{K})$ and less, a value of thermal resistance $\mathrm{R}=4,4(\mathrm{~m} 2 . \mathrm{K} / \mathrm{W})$ and more. From 1 January 2021, these requirements are expected to be tightened for low-energy buildings. The heat transfer value will be equal or less than $\mathrm{U}=$ $0.15 \mathrm{~W} /(\mathrm{m} 2 . \mathrm{K})$, or a thermal resistance greater or equal to $\mathrm{R}=6.5(\mathrm{~m} 2 . \mathrm{K} / \mathrm{W})$. Among the compared structures, the best results were achieved by the euro panel SIP, which has the lowest value of heat transfer $\mathrm{U}=0.25 \mathrm{~W} /(\mathrm{m} 2 . \mathrm{K})$ and the highest value of thermal resistance $\mathrm{R}=3.73(\mathrm{~m} 2 . \mathrm{K} / \mathrm{W})$. A slightly worse value has the ceramic panel, which has a heat transfer $\mathrm{U}=0.26 \mathrm{~W} /(\mathrm{m} 2 . \mathrm{K})$ and a thermal resistance $\mathrm{R}=3.6$ $(\mathrm{m} 2 . \mathrm{K} / \mathrm{W})$. The worst result of the comparison has a CLT panel, which has a heat transfer value of $\mathrm{U}=$ $1.01 \mathrm{~W} /(\mathrm{m} 2 . \mathrm{K})$ and a thermal resistance of $\mathrm{R}=0.82$ $(\mathrm{m} 2 . \mathrm{K} / \mathrm{W})$.

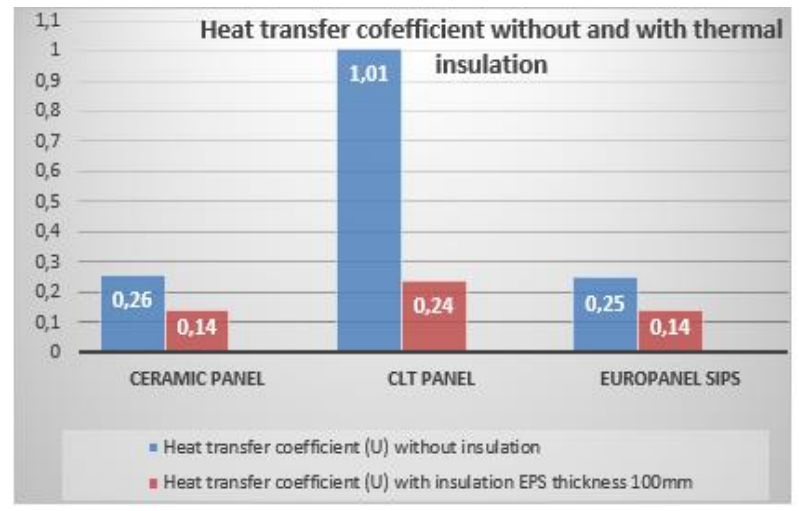

Figure 9. Heat transfer coefficients with and without thermal insulation

Of all three constructional solutions compared at a given thickness, no solution meets the requirements of the construction-technical standard valid from 2013. In order to meet the prescribed standard, thermal insulation of the external wall is necessary. The thermal insulation design shall be determined so that it also complies with the construction and technical standard, which will be applied after 2020.

All three construction solutions are insulated with $100 \mathrm{~mm}$ EPS expanded polystyrene, thermal conductivity $\lambda=0,031 \mathrm{w}(\mathrm{m} / \mathrm{k})$ and thermal resistance $\mathrm{R}=3.2(\mathrm{~m} 2 . \mathrm{K} / \mathrm{W})$. In Figure 9 we can see a graph of heat transfer coefficient for three construction solutions without thermal insulation and also with thermal insulation.

When insulated with expanded polystyrene EPS thickness $100 \mathrm{~mm}$, constructions made of ceramic panel and euro panel, meet the values prescribed by the standard for the current state until 2021 [U = $0.22 \mathrm{~W} /(\mathrm{m} 2 . \mathrm{K})$ and $\mathrm{R}=4.4(\mathrm{~m} 2 . \mathrm{K} / \mathrm{W}))$, but also 
for the stricter standard that will apply after 1.1.2021 $(\mathrm{U}=0.15 \mathrm{~W} /(\mathrm{m} 2 . \mathrm{K})$ and $\mathrm{R}=6.5(\mathrm{~m} 2 . \mathrm{K} / \mathrm{W})]$. In both construction solutions is the heat transfer coefficient $\mathrm{U}=0.14 \mathrm{~W} /(\mathrm{m} 2 . \mathrm{K})$, which is less than the normal value. The thermal resistance for the ceramic panel is $\mathrm{R}=6.83(\mathrm{~m} 2 . \mathrm{K} / \mathrm{W})$ and for the euro panel is $R=6,96(\mathrm{~m} 2 . \mathrm{K} / \mathrm{W})$ which is greater than the normal value. Constructional solution from CLT panels, even with polystyrene insulation EPS with thickness of $100 \mathrm{~mm}$, does not comply with the design values for the standard valid from 1 January 2021. The heat transfer coefficient is $\mathrm{U}=0.24 \mathrm{~W} /$ $(\mathrm{m} 2 . \mathrm{K})$ and the thermal resistance $\mathrm{R}=4.05(\mathrm{~m} 2 . \mathrm{K} /$ $\mathrm{W})$. In order to ensure a condition for the standard valid after 2021, it is necessary to insulate the CLT panels with expanded polystyrene EPS with thickness of $180 \mathrm{~mm}$. It is the same type of polystyrene but with a greater thickness. With such thermal insulation the CLT panels complies with the stricter standard valid after 2020. The heat transfer coefficient is $\mathrm{U}=0.15 \mathrm{~W} /(\mathrm{m} 2 . \mathrm{K})$ and the thermal resistance is $\mathrm{R}=6.6(\mathrm{~m} 2 . \mathrm{K} / \mathrm{W})$.

For the investigation of building components, regarding on how they will react or resist in the event of fire, we can classify the elements into the area according to fire safety. In the case of fire, it is examined how long the building structure can withstand fire and meet the requirements for loadbearing capacity, integrity and insulation (REI). Fire resistance is classified into classes according to resistance time $(15,20,30,45,60,90,180,240$ min.). Another area of fire safety is a reaction to fire. It is investigated that a given building element contributes to the origin and development of fire. This is a stage before a fully developed fire. In this assessment, the building element is classified into classes (A1, A2, B, C, D, E, and F) and evaluated as a whole (e.g. sandwich wall). At the degree of flammability, the element is evaluated separately according to the material of which the element consists. For example, a building element classified in class A1 does not contribute to the spread of fire and is non-flammable. [51] The best in terms of fire safety was the ceramic panel variant, which is classified according to the reaction to fire in class A1, thus non-flammable and according to fire resistance rated as REI 180. The class of reaction to fire is the same for the SIP and CLT euro panel variants, and these design solutions are classified in class D, which means they are moderately flammable. They differ in fire resistance, where the CLT panel is rated REI 90 and the SIP euro panel with REI 20 (Table 1).

The graph (Fig.10) shows that the largest usable area provides a construction solution of CLT panels with $163.66 \mathrm{~m} 2$ of which the living area is $121.03 \mathrm{~m} 2$ and $42.63 \mathrm{~m} 2$ house accessories. As a second structural solution we provide a useful area of 157.81 $\mathrm{m} 2$, it is a variant of ceramic panels, with a living area of $116.98 \mathrm{~m} 2$ and a floor area of accessories of $40.83 \mathrm{~m} 2$. The design of the SIP euro panels with a usable area of $155.51 \mathrm{~m} 2$ ended with less distance, where the living space of the room is $115.47 \mathrm{~m} 2$ and the accessory area is $40.04 \mathrm{~m} 2$. The original design has a usable floor area of 139.82 square meters, of which 92.95 square meters is living space and 46.87 square meters of accessories. The original design does not include the kitchen floor area (1.08-Fig.4) to the living area because the kitchen area is less than $12 \mathrm{~m} 2$. Figure 9 shows a graph of the total usable area together with the residential and family accessory areas for the four construction systems.

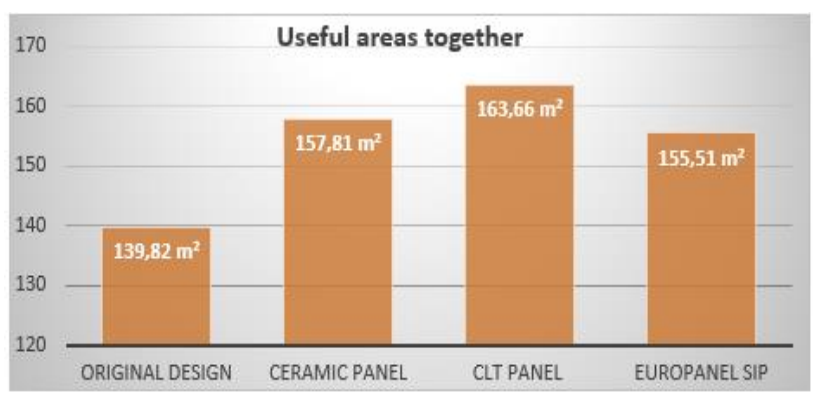

Figure 10. Graph of useful areas (habitable rooms + family house accessories)

The design of CLT panels has the largest increase in useful area compared to the original design. The useful area is $17.05 \%$ larger, which is $23.84 \mathrm{~m} 2$. The structural solution of ceramic panels provides an increase of $12.87 \%$, which is $17.99 \mathrm{~m} 2$. The design variant of SIP euro panels has $11.22 \%$ increase useful area from the original design of $15.69 \mathrm{~m} 2$.

Table 2. Estimation of prices established by firms

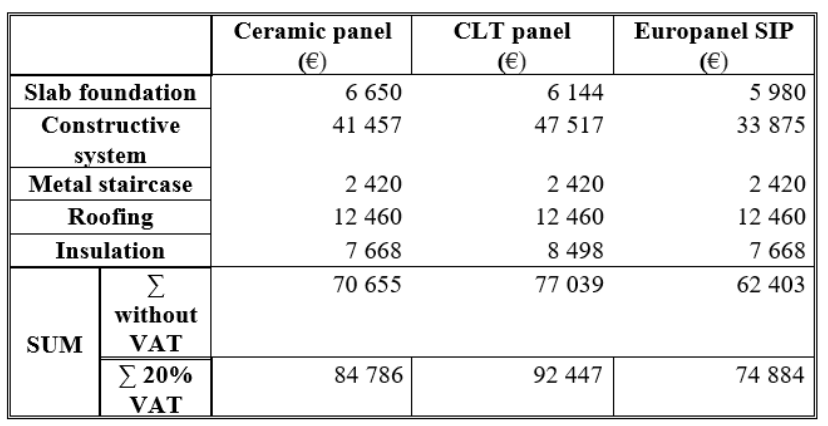

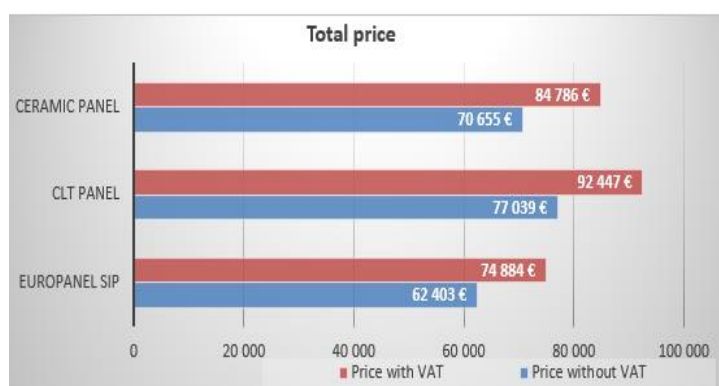

Figure 11. Graph of final price of panel systems with and without VAT 
In order to obtain an estimate of the price of individual prefabricated systems, the companies that are dealing with individual types of prefabrication were directly addressed. Prices are shown in Table 2 , Figure 11.

According to Table 2, we can see that the cheapest variant is from the SIP euro panels with the price of $33875 €$ and the most expensive variant is from CLT panels with the price of $47517 €$. The variant of ceramic panels can be called the middle way, as the price for this variant is $41517 €$. Other items do not differ significantly from one variant to another or do not differ at all, such as for a staircase which is $€$ 2,420 and a roof for which is 12,460 . The thermal insulation of the CLT panel variant is more expensive with $€ 830$ compared to the other two variants, due to use the greater thickness of the EPS polystyrene facade. The price of the slab foundation is different for all three construction variants, but the prices do not differ significantly and the difference between the cheapest and the most expensive slab foundation is only 670 Euros.

\section{Conclusion}

Prefabricated MMC-based systems manufactured in the plant eliminate the occurrence of possible assembly errors when assembling individual systems on site. The aim of prefabrication is to simplify construction activity. Therefore, companies and their production lines offer integrated systems on different material bases with a view to ensuring sustainability. The article performed a cost and technological analysis of prefabricated building systems made of ceramic panels, wooden CLT panels and SIP euro panels, which are suitable for the construction of houses.

\section{Acknowledgements}

The article presents a partial research result of project VEGA 1/0557/18 Research and development of process and product innovations of modern methods of construction in the context of the Industry 4.0 principles.

\section{References}

[1]. NHBC, F. (2016). Modern Methods of Construction, Views from the Industry. IHS BRE Press.

[2]. Bernold, L. E. (2016). Discussion of "Barriers of Implementing Modern Methods of Construction" by M. Motiar Rahman. Journal of Management in Engineering, 32(2), 07015002.

[3]. Doherty, T. (2010). Introduction to MMC \& Eco Construction, Lenders' house building conference, 133.
[4]. Corner, D., Fawcett, R. and Allison, K. (2005). Using Modern Methods of Construction to Build Homes More Quickly and Efficiently, London: National Audit Office Report.

[5]. Dwaikat, L. N., \& Ali, K. N. (2018). Green buildings life cycle cost analysis and life cycle budget development: Practical applications. Journal of Building Engineering, 18, 303-311.

[6]. Afshari, A., Nikolopoulou, C., \& Martin, M. (2014). Life-cycle analysis of building retrofits at the urban scale-a case study in United Arab Emirates. Sustainability, 6(1), 453-473.

[7]. Strauss, A., Frangopol, D., \& Bergmeister, K. (Eds.). (2012). Life-Cycle and Sustainability of Civil Infrastructure Systems: Proceedings of the Third International Symposium on Life-Cycle Civil Engineering (IALCCE'12), Vienna, Austria, October 3-6, 2012. CRC Press.

[8]. Tambouratzis, T. (2016). Analysing the construction of the environmental sustainability index 2005. International Journal of Environmental Science and Technology, 13(12), 2817-2836.

[9]. Kamali, M., Hewage, K., \& Milani, A. S. (2018). Life cycle sustainability performance assessment framework for residential modular buildings: Aggregated sustainability indices. Building and Environment, 138, 21-41.

[10]. Lesniak, A., Zima, K. (2015). Comparison of traditional and ecological wall systems using the AHP method, SGEM Conference Proceedings, 3, 157-164.

[11]. Silvestre, J. D., de Brito, J., \& Pinheiro, M. D. (2013). From the new European Standards to an environmental, energy and economic assessment of building assemblies from cradle-to-cradle (3EC2C). Energy and Buildings, 64, 199-208.

[12]. Roos, A., Woxblom, L., \& McCluskey, D. R. (2008). Architects', and Building Engineers', and Stakeholders' Perceptions to Wood in ConstructionResults from a Qualitative study. In Scandinavian Forest Economics: Proceedings of the Biennial Meeting of the Scandinavian Society of Forest Economics (Vol. 2008, No. 1331-2016-103757, pp. 184-194).

[13]. Kozlovská, M., Struková, Z., \& Tažiková, A. (2014). Integrated assessment of buildings quality in the context of sustainable development principles. Quality innovation prosperity, 18(2), 100-115.

[14]. Hung, C. P., Wei, C., Wang, S. Y., \& Lin, F. C. (2009). The study on the carbon dioxide sequestration by applying wooden structure on eco-technological and leisure facilities. Renewable Energy, 34(8), 18961901.

[15]. Goulding, J., Nadim, W., Petridis, P., \& Alshawi, M. (2012). Construction industry offsite production: A virtual reality interactive training environment prototype. Advanced Engineering Informatics, 26(1), 103-116.

[16]. Smith, R. E. (2011). Prefab Architecture: A Guide to Modular Design and Construction. John Wiley \& Sons. 
[17]. Jain, R. K., Taylor, J. E., \& Peschiera, G. (2012). Assessing eco-feedback interface usage and design to drive energy efficiency in buildings. Energy and buildings, 48, 8-17.

[18]. Pintarič, Z. N., Varbanov, P. S., Klemeš, J. J., \& Kravanja, Z. (2015). Evaluating the economic efficiency of the technologies for greenhouse gas footprint reduction. Chemical Engineering, 45.

[19]. Yong, J. Y., Klemeš, J. J., Varbanov, P. S., \& Huisingh, D. (2016). Cleaner energy for cleaner production: modelling, simulation, optimisation and waste management. Journal of Cleaner Production, 111, 1-16.

[20]. Sathre, R., \& González-García, S. (2014). Life cycle assessment (LCA) of wood-based building materials. In Eco-efficient construction and building materials (pp. 311-337). Woodhead Publishing.
[21]. Ferdous, W., Bai, Y., Ngo, T. D., Manalo, A., \& Mendis, P. (2019). New advancements, challenges and opportunities of multi-storey modular buildingsA state-of-the-art review. Engineering Structures, 183, 883-893.

[22]. Pons, O. (2014). Assessing the sustainability of prefabricated buildings. In Eco-Efficient Construction and Building Materials (pp. 434-456). Woodhead Publishing.

[23]. Galla, J. (2019). Prefabricated Construction. Bachelor Thesis, Technical University of Košice, Faculty of Civil Engineering, Slovakia.

[24]. G SERVIS CZ. (2019). Architecture of family house made of prefabricated elements. Retrieved from: https://pasivnidomy.gservis.cz/ [accessed: 20 April 2020] 